\title{
The use of C-reactive protein in case of preterm labor with intact membranes
}

\section{Tanjona A. Ratsiatosika ${ }^{1 *}$, Randriamahavonjy Romuald ${ }^{2}$, Rajaonarivony Marie Valérie ${ }^{1}$, Rainibarijaona A. Lantonirina ${ }^{1}$, Rakotonirainy Tahiana ${ }^{1}$, Rakotonirina Ando-Miora ${ }^{1}$, Rasolonjatovo Jean de la Croix ${ }^{3}$}

\author{
${ }^{1}$ Department of Public Health, Faculty of Medicine, Antananarivo, Madagascar \\ ${ }^{2}$ Department of Obstetrics and Gynecology, Soavinandriana Hospital Center, Faculty of Medicine Antananarivo, \\ Antananarivo, Madagascar \\ ${ }^{3}$ Department of Obstetrics and Gynecology, Toamasina, Faculty of Medicine Toamasina, Madagascar
}

Received: 15 May 2019

Accepted: 11 June 2019

*Correspondence:

Dr. Tanjona A. Ratsiatosika,

E-mail: ratsiatosika.tanjona@gmail.com

Copyright: () the author(s), publisher and licensee Medip Academy. This is an open-access article distributed under the terms of the Creative Commons Attribution Non-Commercial License, which permits unrestricted non-commercial use, distribution, and reproduction in any medium, provided the original work is properly cited.

\section{ABSTRACT}

Background: Preterm labor, defined as delivery between 22 and 37WA, is the leading cause of perinatal morbidity and mortality. Through this study, we wanted to know if the high CRP rate in preterm labor with intact membranes could be a risk factor for poor prognosis on pregnancy and the newborn.

Methods: We conducted a prospective cohort study from November 1, 2018 to April 31, 2019 at Befelatanana University Hospital of Gynecology-Obstetrics on singleton pregnancies with preterm labor and intact membranes. The population is divided in two groups according to the rate of CRP and we have chosen as a pathological threshold a CRP $\geq 7 \mathrm{mg} / \mathrm{l}$.

Results: We included 71 cases of MAP over 1735 births, or $4.09 \%$, of which $47 \%$ had a CRP $\geq 7 \mathrm{mg} / 1$ (group I) and $51 \%$ a CRP $<7 \mathrm{mg} / \mathrm{l}$ (group II). There was a significant difference in the persistence of uterine contraction after $48 \mathrm{~h}$ of tocolysis in group I and II [p=0.0013, RR $5.20(1.63-16.55)]$ as well as within of delivery $(7.68 \pm 5.33$ versus $21.36 \pm 11.30$ days, $\mathrm{p}<0.05)$. There was no difference in the occurrence of neonatal asphyxia and neonatal infection between the 2 groups. However, the risk of prematurity is high in the group with a high CRP level [RR 1.34 (1.061.70)] $(\mathrm{p}=0.02)$.

Conclusions: In the case of preterm labor with intact membrane, CRP is a determinant of delivery delay, failure of tocolysis, and occurrence of preterm delivery.

Keywords: CRP, Preterm labor, Prematurity, Risk factors

\section{INTRODUCTION}

The premature labor is defined as regular contractions of the uterus resulting in changes in the cervix between 22 weeks of amenorrhea WA and 36 weeks+6 days. Premature delivery complicates in $50 \%$ of cases of preterm labor with intact membranes and in 30\% a premature rupture of the membranes. ${ }^{1}$ It is the leading cause of hospitalization during pregnancy. ${ }^{2}$ It is also the first etiology of maternofetal medical transfer. During preterm labor, all general or local biomarkers of infection are related to the risk of intrauterine infection, premature 
rupture of membranes, preterm birth and neonatal morbidity and / or maternal morbidity. C-reactive protein is one of these biomarkers that is synthesized by the maternal liver in response to a localized or generalized bacterial infection of the body. There is no threshold defining exactly the abnormality during pregnancy, and thresholds between 7 and $20 \mathrm{mg} / 1$ are retained. ${ }^{3}$ Studies on the association of an increase in CRP rate and the prognosis of preterm labor are old with a low level of evidence. According to a recent study, CRP prescribing for the threat of preterm birth is not systematic. ${ }^{4}$

The aim of this study is to determine whether elevated CRP levels when there is preterm labour with intact membranes may be a risk factor for poor prognosis in pregnancy and newborns.

\section{METHODS}

A prospective cohort study was conducted at a University Hospital Center of Obstetrics and Gynecology, Befelatanana, Madagascar, from October 1, 2018 to April 31,2019 , to determine whether high CRP is a risk factor for poor prognosis for pregnancy and the newborn in case of hospitalization for preterm labor with intact membranes. The population was divided into two groups according to the CRP level and we used a pathological threshold of CRP $\geq 7 \mathrm{mg} / \mathrm{l}$. The data were collected anonymously from obstetrical records after collecting the patient's consent for the use of their medical information.

\section{Inclusion criteria}

- We include all patients hospitalized for preterm labor (clinical examination and ultrasound cervix modification (cervical length $<25 \mathrm{~mm}$ ) with regular and painful uterine contractions) with intact membranes, singleton pregnancies, between 22 to 36 weeks and 6 days, having performed a plasmatic levels CRP assay.

- The population is divided according to the rate of CRP and we have chosen as a pathological threshold a CRP $\geq 7 \mathrm{mg} / \mathrm{l}$. Group I consists of patients with $\mathrm{CRP} \geq 7 \mathrm{mg} / \mathrm{l}$ and group II patients with CRP $<7$ $\mathrm{mg} / \mathrm{l}$.

\section{Exclusion criteria}

- Exclusion criteria were the term $<22$ WA or $\geq 37$ WA, premature rupture of membranes, multiple pregnancies, complicated pregnancies of a maternal or fetal pathology requiring therapy other than preterm labor, medical indications of induced prematurity and cases of fetal death in utero.

\section{Parameters}

The variables studied were: the plasmatic rate of CRP, the delay in delivery, the persistence of uterine contraction after 48 hours of tocolysis, the occurrence of premature rupture of membranes after 48 hours of hospitalization, gestational age at birth, delivery route. Regarding the fetal prognosis, the variables studied were: Apgar index at birth, birth weight, the occurrence of neonatal infection and chorioamnionitis.

\section{The maternal characteristics}

Maternal characteristics were collected from the obstetrical file: age, gestity, parity, temperature, body mass index (BMI).

\section{Conduct of the study}

We designed the data collection sheets containing the parameters to be studied as well as the elements of inclusion or exclusion.

The clinical examination of the patient was carried out at the hospital admission; the CRP plasmatic level assay was carried out systematically. Obstetric ultrasound with endovaginal ultrasound for measurement of cervical length was performed.

In a second step, and prospectively, the pregnancy outcomes were noted in the survey sheet using a phone call, to identify the occurrence or not of uterine contraction, premature rupture of membranes after hospitalization, gestational age at delivery, birth weight. The appearance or not of neonatal infection the apgar index, the birth weight have been verified in the neonatology department.

\section{Statistical analysis}

Categorical variables were compared using Khi-square or Fisher's exact tests where appropriate. Significance for all analyses was defined as a p-value $<0.05$. Continuous variables were expressed as mean \pm standard deviation. Student's t-test or Mann-Whitney U-test was used for comparison of parametric variables. We used the $\mathrm{R}$ software for the statistical analysis of the results.

\section{RESULTS}

\section{Epidemiological parameters}

During our study, among 1735 hospitalized at the pathological pregnancy department, we collected 71 cases of MAP or $4.09 \%$ of which $47 \%$ had a CRP $\geq 7$ $\mathrm{mg} / \mathrm{l}$ with an average rate of $13.89 \%$ (group I) and $51 \%$ a CRP $<7 \mathrm{mg} / \mathrm{l}$ with an average rate of $4.63 \%$ (group II). The two groups are identical in their socio-demographic and clinical characteristics such as age, parity, gestational age, number of antenatal care (ANC) and BMI. The mean age was $24.44 \pm 5.70$ years with extremes of 16 and 40 years, mean parity was $1.09 \pm 0.97$ (Table 1). Mean gestational age was $32.98 \pm 1.52$ (Table 1 ). The majority of pregnancies were poorly followed with an average ANC of $3.03 \pm 1.17$ (Table 1). The average body mass 
index was $24.71 \pm 2.20$ (Table 1). There was no hyperthermia in both groups. In group I, $67.65 \%$ of patients had no infectious signs versus $78.38 \%$ in group II; $17.65 \%$ had urinary signs versus $8.11 \%$ in group II, $11.76 \%$ had leucorrhoea versus $10.81 \%$ in group II. There was no significant difference between the 2 groups $(\mathrm{p}=0.69)($ Table 2). The mean bishop score for group I was $7.23 \pm 1.5$ versus $6.73 \pm 1.45$ for group II $(\mathrm{p}=0.09)$ (Table 3 ). The mean leukocyte counts for group I and II were $11.53 \mathrm{G} / \mathrm{l} \pm 3.27,9.95 \mathrm{G} / \mathrm{l} \pm 3.66$ respectively $\mathrm{p}=0.059$ (Table 4).

Table 1: Sociodemographic characteristics of patients.

\begin{tabular}{|c|c|c|c|}
\hline Variables & Group I (CRP $\geq 7 \mathrm{mg} / \mathrm{l}) \mathrm{N}=34$ & Group II (CRP<7mg/l) N=36 & p Value \\
\hline Age (years) mean \pm sd & $24.44 \pm 5.70$ & $24.35 \pm 6.25$ & \multirow{2}{*}{0.94} \\
\hline$(\min -\max )$ & $16-40$ & $14-42$ & \\
\hline Parity mean \pm sd & $1.09 \pm 0.97$ & $1.11 \pm 0.84$ & 0.92 \\
\hline Gestity mean \pm sd & $2.12 \pm 1.07$ & $2.16 \pm 1.01$ & 0.85 \\
\hline \multicolumn{3}{|c|}{ Gestationnal age (weeks of amenorrhea) } & \multirow{3}{*}{0.87} \\
\hline mean \pm sd & $32.98 \pm 1.52$ & $32.92 \pm 1.67$ & \\
\hline$(\min -\max )$ & $28.40-35.3$ & $28.40-35.6$ & \\
\hline \multicolumn{3}{|l|}{ Antenatal care } & \multirow{3}{*}{0.92} \\
\hline mean \pm sd & $3.03 \pm 1.17$ & $3.05 \pm 1.18$ & \\
\hline$(\min -\max )$ & $1-6$ & $1-6$ & \\
\hline BMI $\left(\mathrm{Kg} / \mathrm{m}^{2}\right)$ mean $\pm \mathrm{sd}$ & $24.71 \pm 2.20$ & $24.76 \pm 2.11$ & 0.92 \\
\hline
\end{tabular}

BMI: Body mass index

Table 2: Infectious signs.

\begin{tabular}{|c|c|c|c|}
\hline Variables & Group I (CRP $\geq 7 \mathrm{mg} / \mathrm{l}) \mathrm{N}=34$ & Group II (CRP<7mg/l) N=36 & p value \\
\hline \multicolumn{3}{|l|}{ Signes n (\%) } & \multirow{5}{*}{0.40} \\
\hline No signs & $23(67.65)$ & $29(78.38)$ & \\
\hline Urinary signs & $6(17.65)$ & $3(8.11)$ & \\
\hline Leucorrhea & $4(11.76)$ & $4(10.81)$ & \\
\hline Digestive sign & $1(2.94)$ & $1(2.70)$ & \\
\hline
\end{tabular}

Table 3: Bishop score and cervical length with endovaginal.

\begin{tabular}{|llll|}
\hline Variables & Group I $(\mathrm{CR} \geq 7 \mathrm{mg} / \mathrm{l}) \mathrm{N}=30$ & Group II $(\mathrm{CRP}<7 \mathrm{mg} / \mathrm{I}) \mathrm{N}=36$ & p value \\
\hline BISHOP score mean \pm sd & $7.24 \pm 1.05$ & $6.73 \pm 1.45$ & 0.098 \\
\hline Cervical length $(\mathrm{cm})$ mean \pm sd & $22.91 \pm 3.28$ & $22.59 \pm 3.67$ & 0.70 \\
\hline
\end{tabular}

Table 4: Paraclinical data.

\begin{tabular}{|c|c|c|c|}
\hline Variables & Group I (CRP $\geq 7 \mathrm{mg} / \mathrm{I}) \mathrm{N}=34$ & Groupe II (CRP<7mg/l) N=37 & p value \\
\hline Leukocyte count mean \pm sd & $11.53 \pm 1.05$ & $9.95 \pm 1.45$ & 0.059 \\
\hline \multicolumn{3}{|l|}{ Vaginal swabs n (\%) } & \multirow{5}{*}{0.70} \\
\hline Not done & $29(85.29)$ & $32(86.49)$ & \\
\hline GV & $3(8.88)$ & $2(5.41)$ & \\
\hline $\mathrm{GV}+\mathrm{EC}$ & $2(5.88)$ & $1(2.70)$ & \\
\hline Candida & $0(0)$ & $2(5.41)$ & \\
\hline \multicolumn{3}{|l|}{ Uroculture n (\%) } & \multirow{4}{*}{0.77} \\
\hline Not done & $28(82.35)$ & $33(89.18)$ & \\
\hline Normal & $4(11.76)$ & $4(10.81)$ & \\
\hline $\mathrm{EC}$ & $2(5.89)$ & $0(0)$ & \\
\hline
\end{tabular}

GV: Gardenerella vaginalis, EC: Echerichia Coli.

In our study, the majority of our patients did not perform vaginal swab in group I (85.29\%) versus $86.49 \%$ in group
II $(\mathrm{p}=0.58)$, and that Gardnerella vaginalis was the predominant germ in both groups (Table 4). There was no 
significant difference between the 2 groups regarding the occurrence of vaginal infection $(\mathrm{p}=0.77)$, and the most incriminated organism was Escherichia coli (Table 4). Cervical length measurement averaged $22.91 \mathrm{~cm} \pm 3.23$, identical for both groups $(\mathrm{p}=0.70)$ (Table 3$)$.

\section{Outcome of pregnancy}

In our study, there was a significant difference in the persistence of uterine contraction after $48 \mathrm{~h}$ of tocolysis in group I and II [p=0.0013, RR 5.20 (1.63-16.55)], within the delivery time $(7.68 \pm 5.33$ days versus $21.36 \pm 11.30$ days, $\mathrm{p}<0.05)$, as well as in the occurrence of preterm birth [RR 1.34 (1.06-1.70)] ( $\mathrm{p}=0.02)$ (Table 5).

The vaginal delivery was predominant in both groups $(83.33 \%$ versus $88.89 \%)$, but the difference was not significant $(\mathrm{p}=0.72)$ (Table 5).

Table 5: Obstetrical outcome.

\begin{tabular}{|c|c|c|c|c|}
\hline Variables & $\begin{array}{l}\text { Group I (CRP } \geq 7 \mathrm{mg} / \mathrm{l}) \\
\mathrm{N}=30\end{array}$ & $\begin{array}{l}\text { Group II (CRP<7mg/l) } \\
\mathbf{N = 3 6}\end{array}$ & RR ; IC & p value \\
\hline \multicolumn{4}{|c|}{ Persistence of uterine contraction n (\%) } & \multirow{3}{*}{0.0013} \\
\hline Yes & $13(43.33)$ & $3(8.33)$ & $5.22(1.63-16.55)$ & \\
\hline No & $17(56.67)$ & $33(91.67)$ & & \\
\hline \multicolumn{4}{|c|}{ Occurrence of membrane rupture n (\%) } & \multirow{3}{*}{0.12} \\
\hline Yes & $8(26.67)$ & $4(11.12)$ & $2.4(0.80-7.19)$ & \\
\hline No & $22(73.33)$ & $32(88.89)$ & & \\
\hline Delivery time (Days) & $7.68 \pm 5.33$ & $21.36 \pm 11.30$ & & $<0.05$ \\
\hline \multicolumn{4}{|c|}{ Preterm delivery n (\%) } & \multirow{3}{*}{0,02} \\
\hline Preterm delivery & $28(93.33)$ & $25(69.44)$ & $1.34(1.06-1.70)$ & \\
\hline Term pregnancy & $2(6.67)$ & $11(30.56)$ & & \\
\hline \multicolumn{4}{|l|}{ Delivery route $\mathrm{n}(\%)$} & \multirow{3}{*}{0.72} \\
\hline Vaginal route & $25(83.33)$ & $32(88.89)$ & & \\
\hline Caesarean section & $5(16.67)$ & $4(11.11)$ & $1.50(0.44-5.09)$ & \\
\hline \multicolumn{4}{|c|}{ Chorioamniotitis n (\%) } & \multirow{3}{*}{ Ns } \\
\hline Yes & $0(0)$ & $0(0)$ & & \\
\hline No & $30(100)$ & $36(100)$ & & \\
\hline
\end{tabular}

Table 6: Neonatal outcomes.

\begin{tabular}{|c|c|c|c|c|}
\hline Variables & $\begin{array}{l}\text { Group I (CRP } \geq 7 \mathrm{mg} / \mathrm{l}) \\
\mathrm{N}=30\end{array}$ & $\begin{array}{l}\text { Group II (CRP<7mg/l) } \\
\mathbf{N}=36\end{array}$ & RR IC95\% & p value \\
\hline Birth weight $(\mathrm{g})$ mean \pm sd & $2120.67 \pm 414.55$ & $2561.67 \pm 285.34$ & & $<0.05$ \\
\hline APGAR score M5 mean \pm sd & $9.06 \pm 1.08$ & $9.58 \pm 0.87$ & & 0.035 \\
\hline \multicolumn{4}{|l|}{ Neonatal asphyxia n (\%) } & \multirow{3}{*}{0.58} \\
\hline Yes & 2 & 1 & \multirow{2}{*}{$2.40(0.22-25.19)$} & \\
\hline No & 1 & 35 & & \\
\hline \multicolumn{4}{|l|}{ Neonatal infection $\mathrm{n}(\%)$} & \multirow{3}{*}{1} \\
\hline Yes & $1(3.33)$ & $1(2.78)$ & \multirow{2}{*}{$1.20(0.07-18.38)$} & \\
\hline No & $29(96.67)$ & $35(07.22)$ & & \\
\hline \multicolumn{4}{|l|}{ Neonatal death $\mathrm{n}(\%)$} & \multirow{3}{*}{0.17} \\
\hline Yes & $4(13.33)$ & $1(2.78)$ & \multirow{2}{*}{$4.66(0.55-39.51)$} & \\
\hline No & $26(86.67)$ & $35(97.22)$ & & \\
\hline
\end{tabular}

\section{Neonatal outcome}

The mean APGAR Index at the 5th minute was $9.07 \pm 1.08$, identical in both groups $(p=0.58)$ and there was no difference in the occurrence of neonatal asphyxia $(\mathrm{p}=1)$, neonatal infection $(\mathrm{p}=0.58)$ and neonatal death
( $\mathrm{p}=0.17$ ) between the 2 groups. However, there was a significant difference in birth weight in group I and II, with a respective mean of $(2120.66 \mathrm{~g} \pm 414.55$ versus 2561.66g $\pm 285.34, \mathrm{p}<0.05$ ) (Table 6). 


\section{DISCUSSION}

Of the 71 cases of preterm labor with intact membrane, 34 patients had a high CRP $\geq 7 \mathrm{mg} / \mathrm{l}(47 \%)$, while the 36 patients had a CRP level $<7 \mathrm{mg} / \mathrm{l}(51 \%)$. The frequency of preterm labor was $4.9 \%$ in our study.

The preterm labor is a common obstetric complication that will most likely not lead to premature delivery. ${ }^{5}$ Clinical and biological assessments are used to search for a maternal cause, assess the likelihood of an underlying infection and to estimate outcomes of pregnancy and the newborn. ${ }^{6}$ The CRP is one of the biological markers requested during a preterm labor, and we chose as a pathological threshold a $\mathrm{CRP} \geq 7 \mathrm{mg} / \mathrm{l}$.

Regarding pregnancy outcomes with preterm labor with intact membranes, the results of our study showed that there was a significant difference in the persistence of uterine contraction after 48 hours of tocolysis in both groups $[p=0.0013$ RR 5.20 IC 95\% (1.63-16.55)]. A study by Handwerker SM et al, showed a poor response to tocolytic and high CRP treatment, which is almost similar to our results. ${ }^{7}$ Cammu et al, found that an increase in CRP is more common when tocolysis is ineffective in preterm labor, which was similar to our results. Several authors have shown that a rise of CRP plasmatic level is associated with a shortening of the delivery time. ${ }^{8}$

In our study, a significant difference was demonstrated between the 2 groups in the delivery time $(7.68 \pm 5.33$ versus $21.36 \pm 11.30$ days, $\mathrm{p}<0.05$ ).

According to Dodds WG et al, a CRP $\geq 8 \mathrm{mg} / \mathrm{L}$ identifies with a sensitivity of $85 \%$ a subgroup of patients delivering within one week after plasmatic measurements with a sensitivity of $85 \%$, which is almost identical to our results. ${ }^{9}$ Similarly, Pokkul et al, show that CRP is $\geq 7$ $\mathrm{mg} / \mathrm{L}$ in $40 \%$ of premature deliveries is related to a very significant shortening of the delay of delivery $(14 \pm 5$ versus $35 \pm 4$ days, $\mathrm{p}<0.01)$, similar to our study. ${ }^{10} \mathrm{~A}$ study by Watts et al found a delivery less than 7 days but with a CRP threshold $>15 \mathrm{mg} / \mathrm{l}$ with a sensitivity of $79 \% .{ }^{11}$ Likewise for Cammu $\mathrm{H}$ and his co-workers who had observed a delivery less than 7 days at a CRP threshold $\geq 12.5 \mathrm{mg} / \mathrm{l}$ with a sensitivity of $64 \%$ and a specificity of $90 \% .^{8}$ For these two last authors, a faster delivery time compared to our results was marked, with a higher CRP rate. It can thus be seen that the higher the CRP threshold used, the shorter the delivery period.

Through our study, an increased risk of preterm delivery was found at a CRP level $\geq 7 \mathrm{mg} / \mathrm{l}$ [RR 1.34 (1.06-1.70)] $(\mathrm{p}=0.02)$.

The work of Goffinet et al, who found that CRP (greater than $5 \mathrm{mg} / \mathrm{L}$ or greater than $20 \mathrm{mg} / \mathrm{L}$ ) was a marker significantly associated with preterm delivery, and that CRP >20 mg/L was the most common marker more strongly associated. ${ }^{12}$ In the Kim et al study, preterm labor was found with a CRP level $>4.4 \mathrm{mg} / \mathrm{l}$ but with a sensitivity of $40 \%$ and a specificity of $89 \% .{ }^{13}$ The higher the pathological threshold of CRP used, the risk of premature delivery is marked.

Intra-uterine or amniotic fluid infection define the existence of an intrauterine infection for which it is necessary to distinguish the ruptured membranes chorioamnionitis (which occurs in a context of rupture of the membranes and is found excluded from this study) and intact membrane chorioamnionitis. ${ }^{14}$

The results of our study showed no cases of choriamniotitis in both groups. On the other hand, Yoon $\mathrm{BH}$ et al, had shown that a concentration of CRP greater than $7 \mathrm{mg} / \mathrm{L}$ is significantly associated with an increased risk of histological chorioamnionitis. ${ }^{15}$ Similarly, a study by Watts et al, showed an association with clinical chorioamnionitis and CRP >15 mg/l. ${ }^{11}$ Kayem $\mathrm{G}$ et al. Similarly reported the occurrence of clinical chorioamnionitis at CRP >18 mg/l. ${ }^{6}$ The absence of chorioamnionitis in our study could be explained by the fact that chorioamnionitis are considered in studies to be more often the result of premature rupture of the membranes than of the preterm labor with intact membranes. Moreover, the CRP rate we have chosen is very low $(7 \mathrm{mg} / \mathrm{l})$. Indeed, for Bessières et al, a CRP level $>50 \mathrm{mg} / \mathrm{l}$ associated with maternal fever were signs of chorioamnionitis. ${ }^{16}$ For Fisk, repeated values $\geq 20 \mathrm{mg} / 1$ have a good predictive value for the occurrence of histological chorioamnionitis. ${ }^{17}$

For neonatal outcomes, our study showed that CRP $\geq 7$ $\mathrm{mg} / \mathrm{l}$ (group II) was not a risk factor for neonatal infection and CRP $<7 \mathrm{mg} / \mathrm{l}$ (group I). Cammu et al in their studies had not found a neonatal infection with a CRP level $\geq 12.5 \mathrm{mg} / 1 .{ }^{8}$ On the other hand, according to Watts et al, a neonatal infection was found with a CRP level $>15$ $\mathrm{mg} / \mathrm{l}$, likewise in the study conducted by Goffinet $\mathrm{F}$ et al, with a CRP level $>20 \mathrm{mg} / 1 .{ }^{11,12}$

In Kayem $\mathrm{G}$ et al, study, CRP elevation has a sensitivity of 70 to $80 \%$ for the occurrence of a neonatal infectious complication, but a positive predictive value of only $22 \%$ for the onset of a neonatal or maternal complication, notably because of a lack of specificity (close to $40 \%)^{6}$ Similar results were obtained using a limit of $8 \mathrm{mg} / \mathrm{L}$ in a study by Mazor $\mathrm{M}$ et al. ${ }^{18}$ In practice, higher thresholds of 15 to $20 \mathrm{mg} / \mathrm{L}$ seem more appropriate because of fewer false positives but at the expense of sensitivity. ${ }^{10,19}$

In our study, apart from prematurity and low birth weight, there was no significant difference in the occurrence of neonatal asphyxia or neonatal death in the 2 groups. Asphyxia is often a direct complication of intrauterine infection. Indeed, chorioamnionitis increases the risk of hypoxia four times $[\mathrm{OR}=4.2(1.4-12.0)] .^{20,21}$ This clinical situation does not exist in the two groups 
studied. Thus high CRP isolated during a threat of preterm birth is not a risk factor for neonatal asphyxia.

The limitation of this study is that it is a monocentric study with a limited population. We have many patients who have not been able to benefit from vaginal swabs and/ or uroculture. Newborns did not benefit from biological sampling at birth which can lead to a decrease in the number of neonatal infections. The lack of $\mathrm{pH}$ at the umbilical cord requires us to use the Apgar index less than seven in the fifth minute to diagnose non-specific neonatal asphyxia. A multicenter study with a larger size would be needed to provide evidence of the use of this bioassay during a preterm labor.

\section{CONCLUSION}

Premature labor remains one of the main problems facing obstetrics. Several studies were conducted to evaluate the predictors of preterm labor in order to provide adequate care. Our study showed that high CRP levels are a determining factor in the delay in delivery, the failure of tocolysis, and the occurrence of preterm birth in intact membrane preterm labor. CRP is an easy, inexpensive and accessible even in developing countries. Despite the lack of consensus on its usefulness during a preterm labor, we propose its systematic prescription for the initial assessment to predict the prognosis and the therapeutic response.

\section{Funding: No funding sources}

Conflict of interest: None declared

Ethical approval: The study was approved by the Institutional Ethics Committee

\section{REFERENCES}

1. Goldenberg RL, Culhane JF, Iams JD, Romero R. Epidemiology and causes of preterm birth. Lancet. 2008;371:75-84.

2. Cabrol D, Goffinet F, Carbonne B, Dreyfus M. Menace d'accouchement prématuré et travail prématuré à membranes intactes: physiopathologie, facteurs de risque et conséquences. J Gynecol Obstet Biol Reprod. 2002;31:7-128.

3. Hvilsom GB, Thorsen P, Jeune B, Bakketeig LS. Creactive protein: a serological marker for preterm delivery? Acta Obstet Gynecol Scand. 2002;81:4249.

4. Kayem G, Lorthe E, Doret M. Prise en charge d'une menace d'accouchement prématuré. J Gnecol Obstet Biol Reprod. 2016;45:1364-73.

5. Van Baaren GJ, Vis JY, Grobman WA, Bossuyt PM, Opmeer BC, Mol BW. Cost-effectiveness analysis of cervical length measurement and fibronectin testing in women with threatened preterm labor. Am J Obstet Gynecol. 2013;209:436.e1-8.

6. Kayem G, Maillard F, Schmitz T, Jarreau PH, Cabrol D, Breart G, et al. Prediction of clinical infection in women with preterm labour with intact membranes: a score based on ultrasonographic, clinical and biological markers. Eur J Obstet Gynecol Reprod Biol. 2009;145:36-40.

7. Handwerker SM, Tejani NA, Verma UL, Archbald F. Correlation of maternal serum C-reactive protein with outcome of tocolysis. Obstet Gynecol. 1984;63:220-4.

8. Cammu H, Goossens A, Derde MP, Temmerman M, Foulon W, Amy JJ. C-reactive protein in preterm labour: association with outcome of tocolysis and placental histology. $\mathrm{Br} \quad \mathrm{J}$ Obstet Gynaecol. 1989;96:314-9.

9. Dodds WG, Iams JD. Maternal C-reactive protein and preterm labor. J Reprod Med. 1987;32:527-30.

10. Pokkul PK, Mourad AH, Ponto KI. The association of subclinical infection with preterm labor: the role of C-reactive protein. Am J Obstet Gynecol. 1985;153:642-51.

11. Watts DH, Krohn MA, Hillier SL, Wener MH, Kiviat NB, Eschenbach DA. Characteristics of women in preterm labor associated with elevated Creactive protein levels. Obstet Gynecol. 1993;82:509-14.

12. Goffinet F, Maillard F, Mihoubi N, Kayem G, Papiernik E, Cabrol D, et al. Bacterial vaginosis: prevalence and predictive value for premature delivery and neonatal infection in women with preterm labour and intact membranes. Eur J Obstet Gynecol Reprod Biol. 2003;108:146-51.

13. Kim MA, Lee BS, Park YW, Seo K. Serum markers for prediction of spontaneous preterm delivery in preterm labour. Eur J Clin Invest. 2011;41:773-80.

14. Romero R, Gomez R, Chaiworapongsa $\mathrm{T}$, Conoscenti G, Kim JC, Kim YM. The role of infection in preterm labour and delivery. Paediatr Perinat Epidemiol. 2001;15:41-56.

15. Yoon BH, Yang SH, Jun JK, Park KH, Kim CJ, Romero R. Maternal blood C-reactive protein, white blood cell count, and temperature in preterm labor: a comparison with amniotic fluid whiteblood cell count. Obstet Gynecol. 1996;87:231-7.

16. Bessières $\mathrm{B}$, Bernanrd $\mathrm{P}$. Les chorio-amniotites: aspects cliniques, biologiques et implications médicolégales. Gynecol Obstet Fertil. 2011;39:3837.

17. Fisk N, Fysh J, Child A, Gatenby P, Jeffery H, Brandfield $\mathrm{A}$. Is $\mathrm{C}$-reactive protein really useful in preterm premature rupture of the membranes? $\mathrm{Br} \mathrm{J}$ Obstet Gynaecol. 1987;94:159-64.

18. Mazor M, Kassis A, Horowitz S, Wiznitzer A, Kuperman O, Meril C, et al. Relationship between Creactive protein levels and intraamniotic infection in women with preterm labor. J Reprod Med. 1993;38:799-803.

19. Pitiphat W, Gillman MW, Joshipura KJ, Williams PL, Douglass CW, Rich-Edwards JW. Plasma Creactive protein in early pregnancy and preterm delivery. Am J Epidemiol. 2005;162:1108-13.

20. Murphy DJ, Sellers S, MacKenzie I, Yudkin PL, Johnson AM. Case-controlstudy of antenatal and 
intrapartum risk factors for cerebral palsy in very preterm singleton babies. Lancet. 1995;346:1440-54.

21. Boog G. Cerebral palsy and perinatal asphyxia (IDiagnosis). Gynecol Obstet Fertil. 2010;38:261-77.
Cite this article as: Ratsiatosika TA, Romuald R, Valérie RM, Lantonirina RA, Tahiana R, AndoMiora R, et al. The use of C-reactive protein in case of preterm labor with intact membranes. Int J Reprod Contracept Obstet Gynecol 2019;8:3078-84. 